\title{
CARTOGRAPHIC PRESENTATIONS OF BORDERS ON OLD MAPS OF SLOVENIA
}

DOI: https://doi.org/10.18509/AGB.2018.08

UDC: 528.93:94(497.4-04)"15/18"

\author{
Primož Gašperič, Drago Perko, Matija Zorn \\ Research Center of the Slovenian Academy of Sciences and Arts, \\ Anton Melik Geographical Institute, Slovenia \\ Corresponding author: primoz.gasperic@zrc-sazu.si
}

Submitted: 27.02.2018, Accepted: 10.03.2018, Published: 30.09.2018

\begin{abstract}
Using a uniform methodology, we explored cartographic elements on almost sixty medium-scale maps showing Slovenian territory from the sixteenth to nineteenth centuries. One of the elements examined was also borders, which are very fragmented due to the great landscape diversity of Slovenia. We were interested in how borders in different periods follow the natural boundaries of the landscape and how they are cartographically represented. Lines and shapes were mostly used to display the borders. Shaded areas are more common. They are usually colored or patterned. Lines are more effective. Typically, there are different types, varying in shape, thickness, and color. Only a dozen of the maps examined lack borders. Two-thirds of the maps highlight the borders with a color.
\end{abstract}

Keywords: geography, history of cartography, maps, borders, Slovenia

\section{INTRODUCTION}

Various methods have been used to represent the borders of political, administrative, and similar units. The most common are lines and areas. Areas are most often marked in color, various shades, or with a pattern. Using lines is considered more efficient, and it offers more variation:

- Lines made of various dots;

- Lines made of short horizontal or vertical dashes;

- Solid lines of different weights;

- Lines made of a series of different symbols (e.g., crosses);

- Colored lines.

Combinations of these depiction methods are common.

\section{BORDERS ON OLD MAPS}

In the past, state borders were not precisely defined in terms of territory, and this made drawing borders on maps difficult. It was often not known who controlled places that were remote, subject to frequent warfare, or on the border between two powerful entities. "During the Middle Ages, there is some evidence that the feudal system was more concerned with the control of cities and territories, which, rather than having clear boundaries, had somewhat vague borderlands" [1]. "Thanks to geographers, however, mapping technology allowed rulers to have a spatial view of their possessions; thus, what were originally borderland or border regions progressively became boundaries" [1]. Thus, when maps became a reference for international agreements, especially with the Treaty of Paris after the First World War [1], static lines were put on maps as borders.

The main categories of morphological classification of political borders are: 1) anthropogeographic or geometric borders, usually following straight lines (e.g., a parallel or meridian); and 2) physiographic borders, following some notable natural geographic element in the area, such as orographic lines, ridges, or watercourses [2]. The last are often 
called natural boundaries, even though virtually all political borders, including those based on natural features, are the result of human activity and as such purely artificial. Today's border of Slovenia is mostly adapted to natural conditions. For example, the $654 \mathrm{~km}$ Slovenian-Croatian border is mostly adapted to natural conditions. Natural borders are the most favorable from the perspective of defense strategy, and partly also from the economic point of view [3]. The historical and geographical development of the SlovenianCroatian border area shows that the borders between the historical provinces and other political units were already based on natural boundaries in the past, such as the border between Austria and Hungary within the Habsburg Monarchy. In sections that rely on natural elements, the border between today's independent countries of Slovenia and Croatia has generally remained unchanged since the late Middle Ages [3]. In total, almost exactly four-fifths of the boundary passes along rivers and streams (a hydrographic border) and follows hill ridges (an orographic border). Similar is true for the borders of today's Slovenia with its three other neighboring countries and for historical borders in the territory of today's Slovenia.

Maps from the first centuries of the modern era mostly had a smaller scale and were intended for the public; therefore, there was no need from the cartographic perspective to precisely indicate borders, and for the average user any error in the course of the border did not create a problem. Until the seventeenth century, many maps did not show borders at all (Figure $1)$.

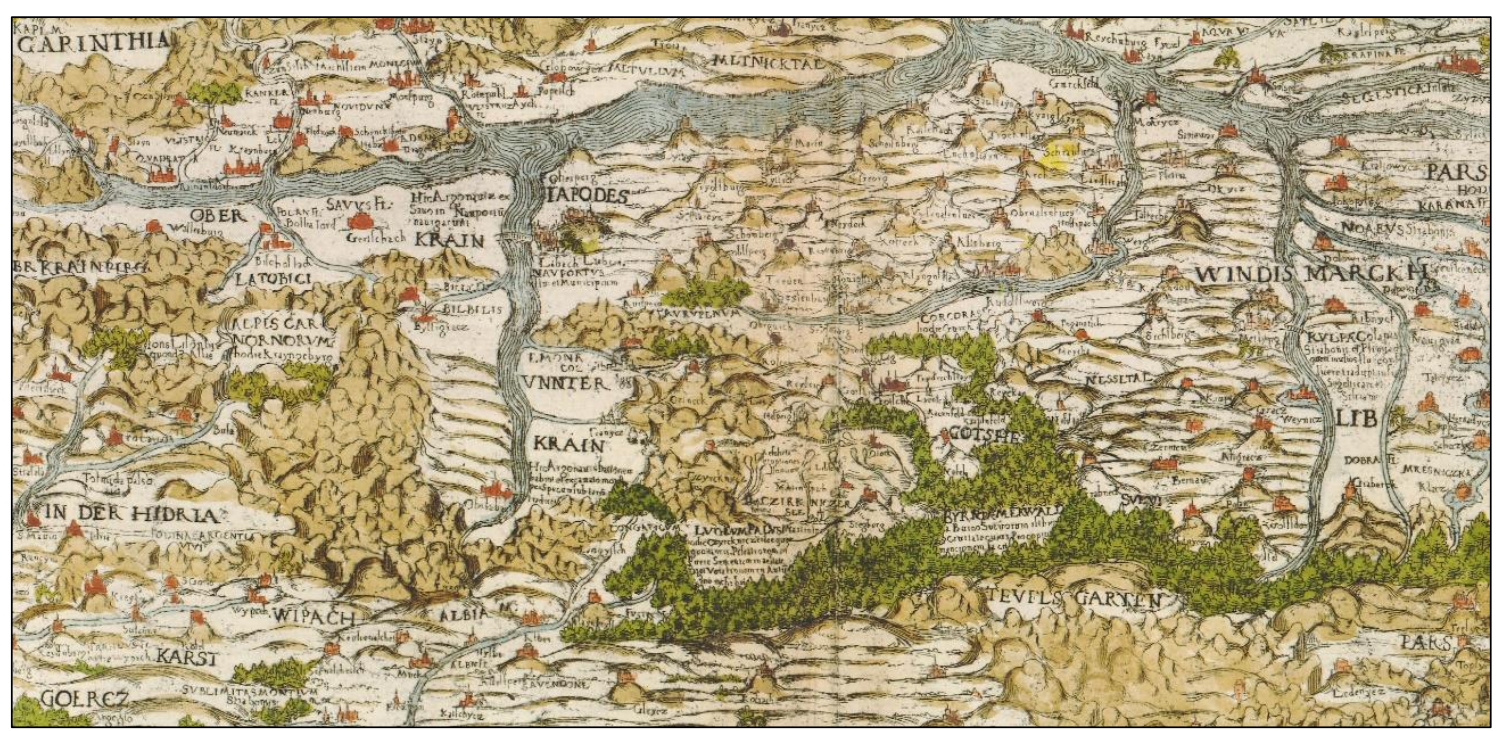

Figure 1. No borders are shown on a mid-sixteenth-century map (of the Sava River approximately between Ljubljana and Zagreb; [4]).

The borders of political entities were shown in various ways. Because it was difficult to depict a border with lines, other means were also used:

- A name was written across an area, and its size and typeface indicated the status and which country the area was part of;

- The area was marked with a symbol of a size corresponding to its status or importance;

- The central part of the area was marked with a special cartographic symbol;

- From the seventeenth century onward

(Figures 2 and 3), areas were also colored (before this, maps were mostly black and white). A stronger ethnic identity developed in Europe in the nineteenth century along with the development of nation-states [5].

Shades of color helped in depicting an individual area. Stronger shades of color faded toward the border and gradually transitioned into a shade of another color of a neighboring area. In the fifteenth and sixteenth centuries, cartographers also used natural barriers to help depict borders.

An individual area was colored up to a river, forest, or mountain range, which assumed the 
role of a border on the map. From the seventeenth century onward, due to new discoveries and therefore greater familiarity with territories, borders became increasingly precise and marked. The Treaty of Karlowitz, concluded in 1699 in Sremski Karlovci (now Serbia), which ended the Great Turkish War between the Habsburg Monarchy and the Ottoman Empire, changed the importance and character of political borders in southeast Europe. For the first time, the state border was physically demarcated on the ground in this part of Europe, and so it was also more precisely demarcated on maps. Lines became the established method for depicting borders and continue to be the most frequently used method even today. In addition to lines of varying weights showing various types of borders, from the seventeenth century onward a combination of line methods was used. Individual areas were colored with the same color as the border, but in a lighter shade $[8, \mathrm{p}$ 47-49].

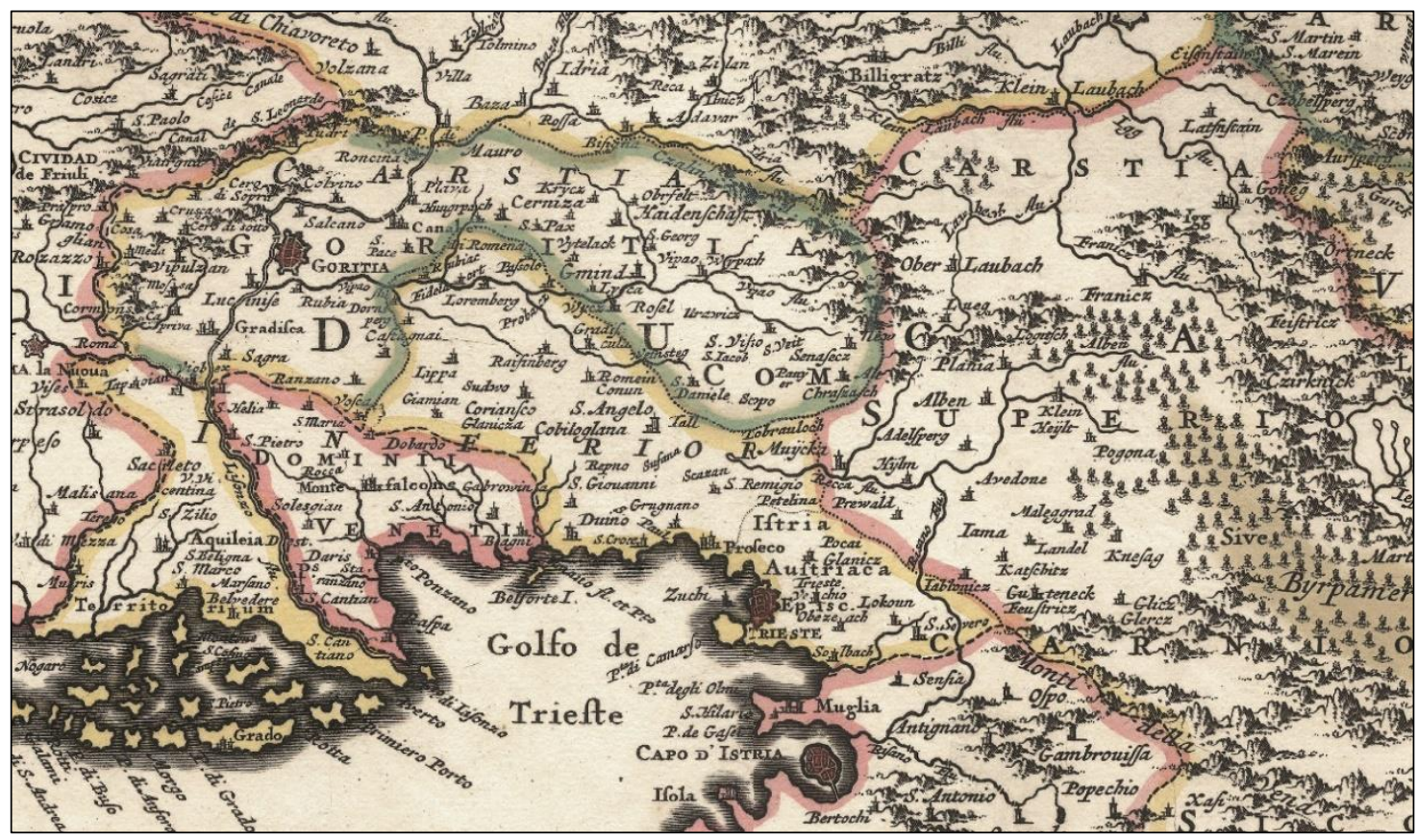

Figure 2. On a mid-seventeenth-century map (of the territory north of the Gulf of Trieste) borders are depicted with colored margins [6].

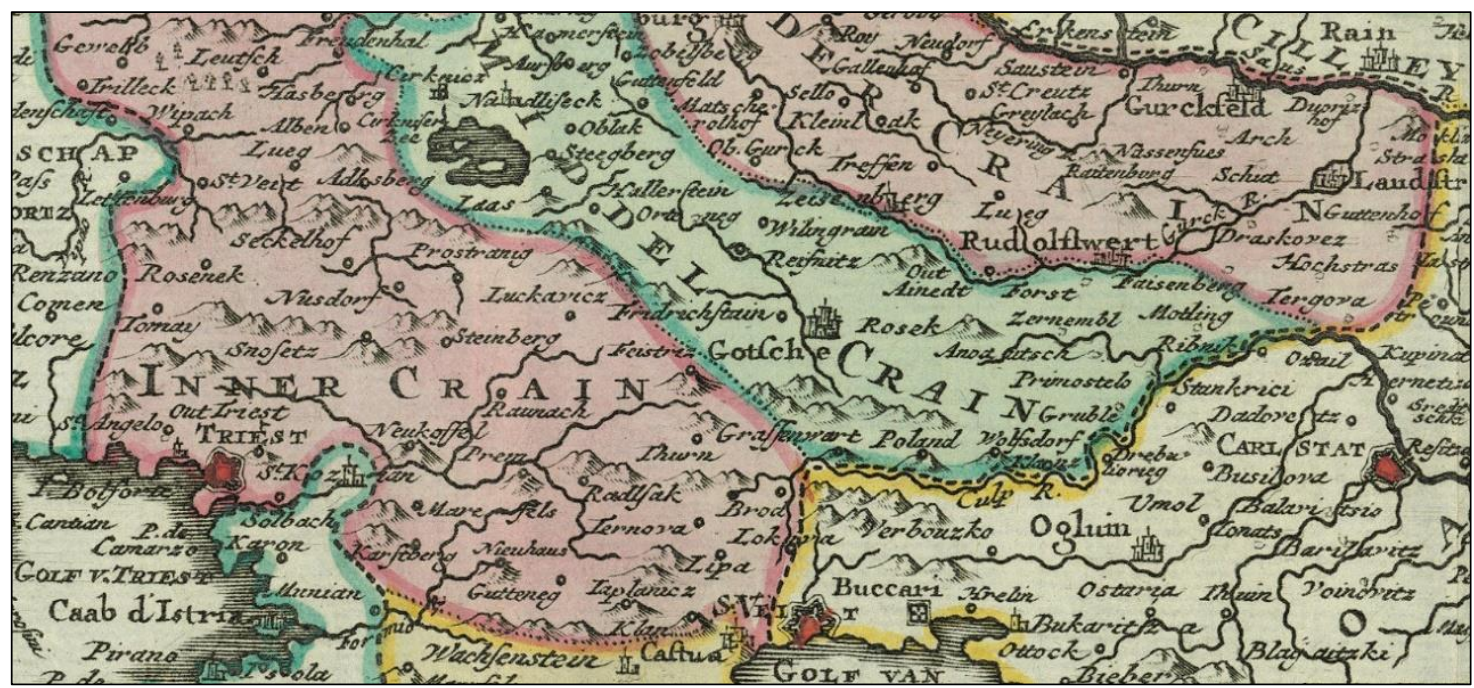

Figure 3. Borders are shown in color on a map from the end of the eighteenth century (of territory north of the Gulf of Trieste and Kvarner Gulf; [7]). 


\section{THE METHODOLOGY OF STUDYING BORDERS ON OLD MAPS}

This research is based on a special data form that makes it possible to analyze changes in cartographic elements through time using a uniform methodology. The preparation of a uniform methodological basis for maps during the period from the mid-sixteenth century to the end of the nineteenth century was a special challenge because such maps differ greatly in technique and form, and their cartographic elements are also presented in very different ways.

We compiled the data form based on five groups of cartographic elements [9]. These are: natural features, built features, geographical names, mathematical elements; and explanatory elements. Cartographic depictions of borders are classified as built features.

The selection of certain groups of elements and their more precise hierarchical arrangement is not new. Several researchers have divided cartographic elements on large-scale topographic maps into two groups: geographical and mathematical elements [10], or natural and built features [11, p 19].

Some have distinguished between three groups: natural features, manmade (built) features, and geographical names [12]. Other use four groups: mathematical, natural geographical, social geographical, and other elements [13, p 221], or a mathematical basis, geographical features, editing information, and additional elements [10, p 12].

Some authors have used an arbitrary division of groups and individual elements; for example, based on their emphasis on the map or the tendency to highlight them $[14 ; 15]$. All of these divisions share the goal of clearly categorizing map content.

This study included fifty-eight maps from the mid-sixteenth century to the end of the nineteenth century showing the territory of today's Slovenia in full or in large part (e.g., the province of Carniola). Maps were excluded if they were the same or similar depictions by the same cartographer, had the same scale, and had the same cartographic representation, or were reprints that differed only in colors or additions that do not affect the cartographic representation (these are frequent in the maps by Homann, Mannert, Kindermann, and Mercator). Maps were included with a scale between 1:200,000 and 1:900,000; that is, medium-scale maps [13, p 219] or large-scale topographic maps [12, p 9]. The majority of maps did not have a scale printed on them, and so this was calculated on the basis of five selected distances on each map.

The borders were mostly marked with simple single lines, and in places with color or a transition between two different colored areas. The following were entered in the data form: depiction method (point: geometric or stylized symbol; line: single or parallel line; area: geometric symbol, stylized group of symbols, colored area), and graphic variables (shape, size, color, brightness, pattern, direction). It was separately marked whether the border was emphasized with a colored margin or band (Figure 4). The maps were analyzed using the data form separately for each individual map. On the data form, an individual group of cartographic elements was selected (e.g., built features), a group of display methods was defined (e.g., borders), and the display methods were defined that the map contains (e.g., linear symbols). Then the selected display method was assessed with the help of graphic variables. Their categorization and explanation were summarized following Fridl [16, p 92-102], who refers to the French cartographer Jacques Bertin and his systematic processing of cartographic means of expression (e.g., [17]), which are considered display methods in this study of the display of borders. Cartographic symbols or display methods are divided based on their extent or type of feature displayed [16, p 89] into points, lines, and areas. These expressions are used in the remainder of this article. The maps were analyzed using the data form separately for each individual map. On the data form, an individual group of cartographic elements was selected (e.g., built features), a group of display methods was defined (e.g., borders), and the display methods were defined that the map contains (e.g., linear symbols). Then the selected display method was assessed with the help of graphic variables. Their categorization and explanation were summarized following Fridl [16, p 92-102], who refers to the French cartographer Jacques Bertin and his systematic processing of cartographic means of 
expression (e.g., [17]), which are considered display methods in this study of the display of borders. Cartographic symbols or display methods are divided based on their extent or type of feature displayed [16, p 89] into points, lines, and areas. These expressions are used in the remainder of this article.

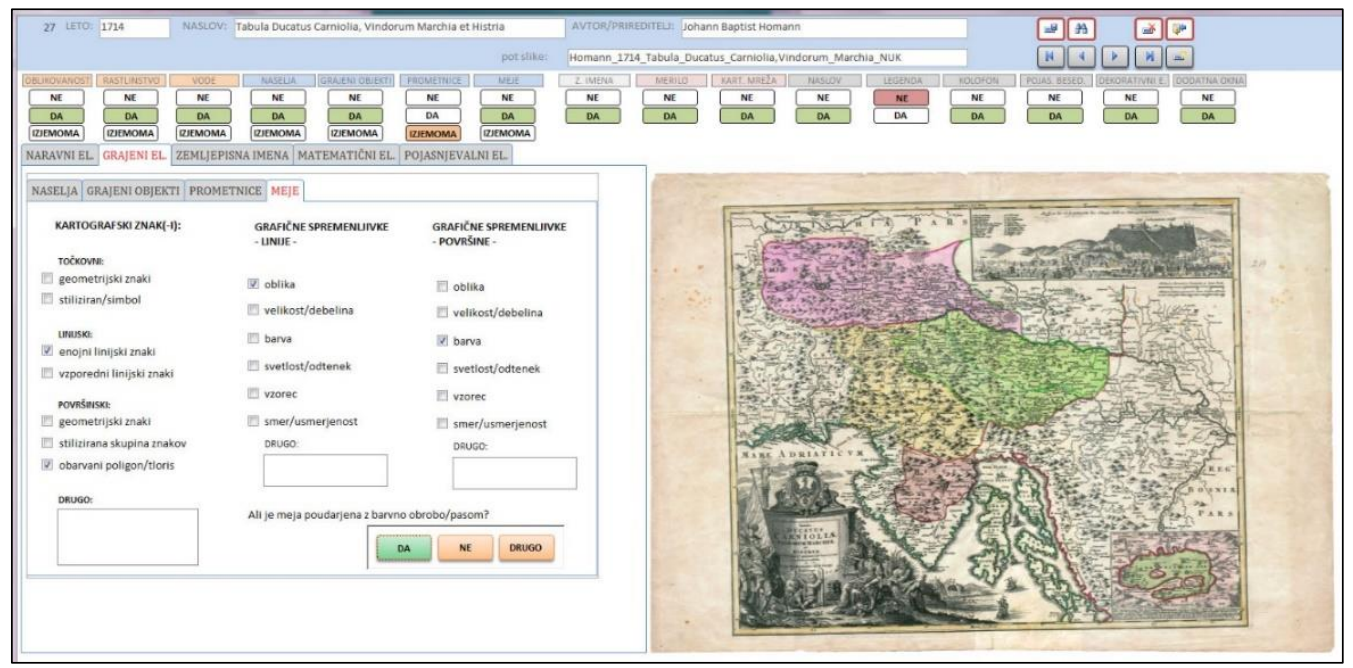

Figure 4. One of the windows in the data form dedicated to borders.

The maps were analyzed using the data form separately for each individual map. On the data form, an individual group of cartographic elements was selected (e.g., built features), a group of display methods was defined (e.g., borders), and the display methods were defined that the map contains (e.g., linear symbols). Then the selected display method was assessed with the help of graphic variables. Their categorization and explanation were summarized following Fridl [16, p 92102], who refers to the French cartographer Jacques Bertin and his systematic processing of cartographic means of expression (e.g., [17]), which are considered display methods in this study of the display of borders. Cartographic symbols or display methods are divided based on their extent or type of feature displayed [16, p 89] into points, lines, and areas. These expressions are used in the remainder of this article.

Especially on the oldest maps, individual display methods are indistinct and not uniform (e.g., nonuniform linear representation), and so it is difficult to define individual qualities (e.g., for graphic variables). Because of poor technical resources and knowledge, as well as inconsistent use of symbols and definitions regarding map structure, on older maps the individual display methods are drawn without rules. The result is idiosyncratic representations that are often difficult to make uniform or place into an individual assessment category. In order to avoid this difficulty, uniform rules for assessment were defined. All of the basic display methods (points, lines, and areas) were found for marking borders, and these were then divided into various types.

\section{RESULTS}

The study took place in various directions. Of interest were the basic characteristics of depicting borders on the selected maps: when they were produced and the depiction methods used, which were further categorized. Then the depiction methods were defined that made it possible to assess the graphic variables.

Borders are shown on $95 \%$ (fifty-two) of the maps. Until the first half of the seventeenth century, borders were rarely marked. Later they were marked on all maps, with the exception of one (Figure 5). A colored margin is used to emphasize the border on 66\% (thirtyeight) of the maps.

Until the second half of the seventeenth century, only three maps had borders with colored margins. Later, colors appear on maps until the end of the period studied. On $84 \%$ (forty-nine) of the maps, the border is marked with a single line, and on $24 \%$ (fourteen) of them it is marked with a colored area. 
Before the end of the sixteenth century, the borders on two maps are marked with a colored area, and this is not found in the seventeenth century. Colored areas appeared more often during the eighteenth century; in the nineteenth century, they are found only on one map from 1873. The use of single lines for borders during the period studied appears in a different order than colored areas. Until the 1630 s, they appear only on one map from 1589, whereas later they are very common and uniform throughout the entire period. From the 1630s onward, the method of depicting the border as a single line over a colored area greatly predominates.

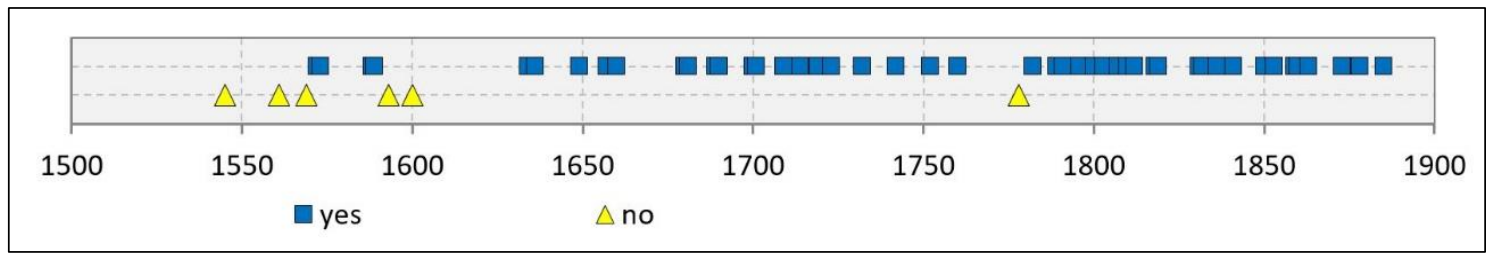

Figure 5. Depictions of borders on maps during the period studied.

Graphic variables were assessed for linear and area methods of depiction because (individual) points are unable to show borders. It was determined that the graphic variables of shape and size appear for linear symbols, and color for area symbols.

The shape defines the appearance of a cartographic symbol, but it does not influence its position on the map. In general, a linear symbol can be shown with a nearly unlimited number of different shapes [16, p 93]. The symbols that comprise a linear representation can have a regular or geometric shape (e.g., circles or dashes) or an irregular shape (e.g., trees and lines of varying length and thickness). Understanding shapes can be complicated because people often subconsciously compare certain shapes with those already known. Therefore it is good to always use more familiar cartographic symbols to depict the same feature and to change them as little as possible [18, p 82].

The size of cartographic symbols is used to depict quantified information. Most often, these change according to selected mathematical principles (e.g., lines of varying weight). Their size must be in a suitable proportion with the numerical values of features $[16, \mathrm{p}$ 94; 14, p 319]. People can simultaneously distinguish up to twenty degrees of size, but to make a clear distinction it is most suitable to use up to five symbols of the same type but of different sizes [18, p 76]. For size differences in lines whose thickness varies between 0.1 and $3 \mathrm{~mm}$, for example, it is most suitable to vary the line thickness by steps of $0.3 \mathrm{~mm}$ [11, p 46].

Among the graphic variables, color has the strongest psychological effect. Color can attract map readers and catch their attention, and cartographers can use it to emphasize content. Assessing color as a graphic variable can be very demanding because it is necessary to know the characteristics of the following dimensions: hue, brightness, and saturation [16, pp 96-98]. In assessing area depictions of borders on old maps, it was possible to only focus on identifying the colors used with the bare eye.

For linear depictions of the border, on $60 \%$ (thirty-five) of the maps we found the shape used, and on $19 \%$ (eleven) size.

From the second half of the seventeenth century onward, the shape and size of the linear border depictions change, but the shape is much more common. It is characteristic that before this there were no differences in depicting borders.

In area depictions, only color is used. On $24 \%$ (fourteen) of the maps color depiction was found and the other variables were not represented.

Depictions with variously colored areas are chronologically very dispersed. This display method was more common in the eighteenth century.

Taking all of the maps analyzed into account, it can be concluded that borders are mostly drawn using shapes and size in linear depictions, and with colors in area depictions (Figure 6). 


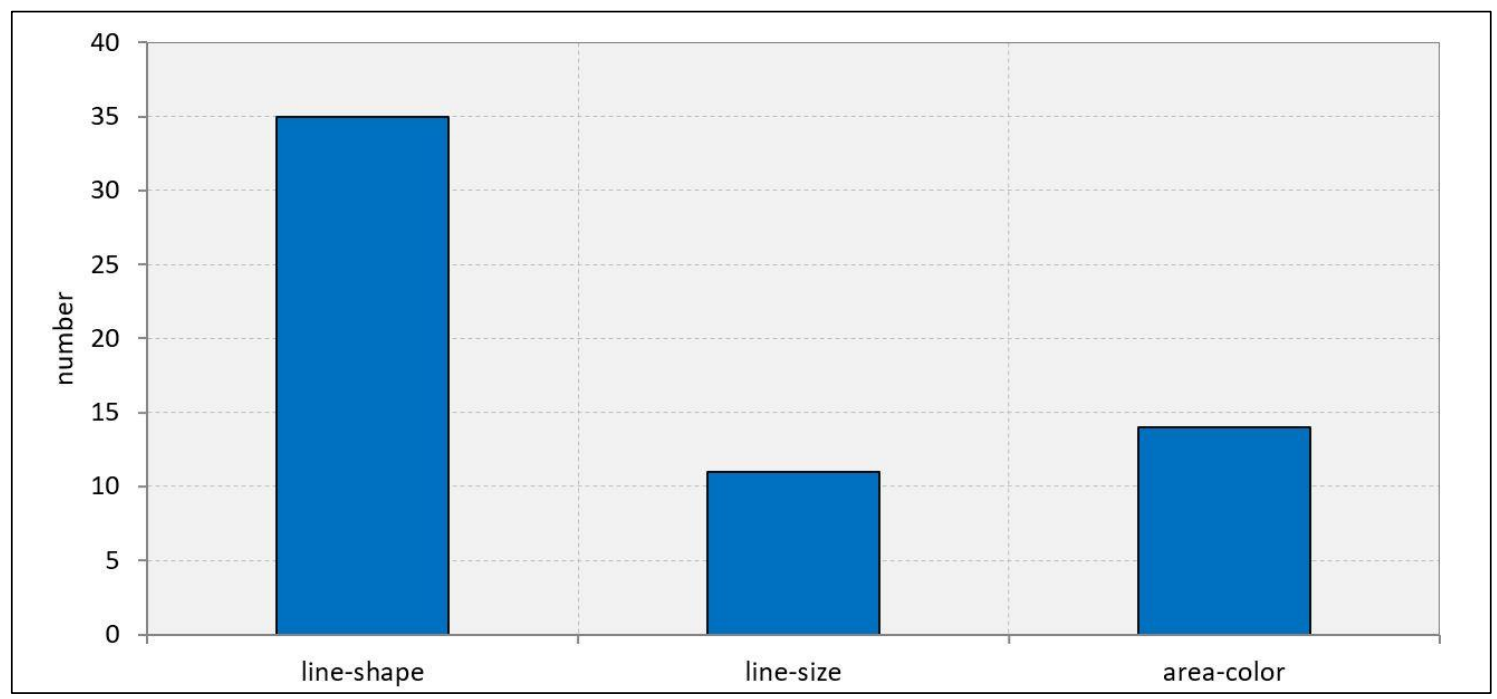

Figure 6. Use of graphic variables in all methods of depicting the border.

Taking into account the graphic variables, until the second half of the seventeenth century the borders of areas were shown with colors, and later also with the size and shape of lines (Figure 7).

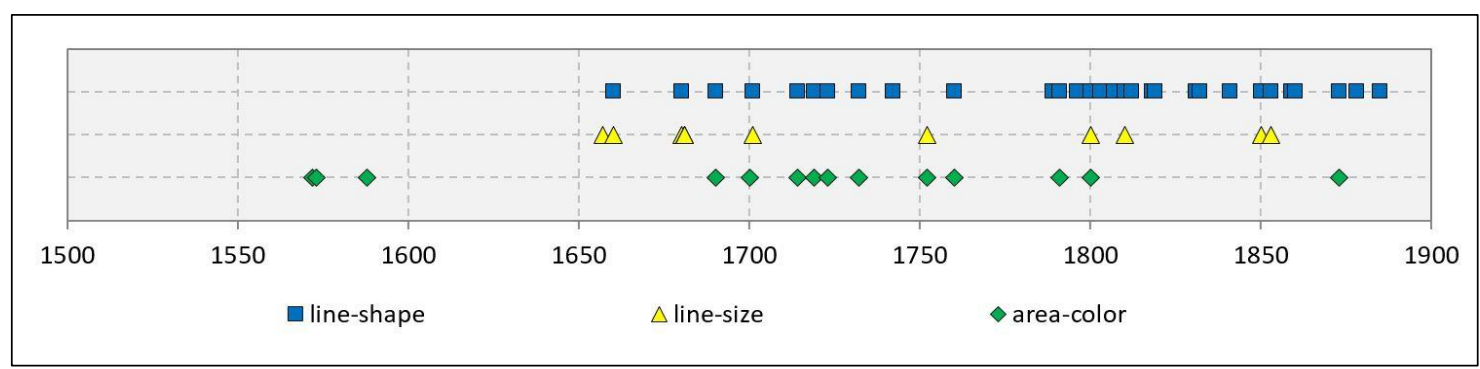

Figure 7. Use of graphic variables in methods of depicting borders during the period studied.

Taking into account the method of representation, single lines predominate over colored areas. Such lines appear throughout the entire period studied, and colored areas are most common on eighteenth-century maps (Figure 8).

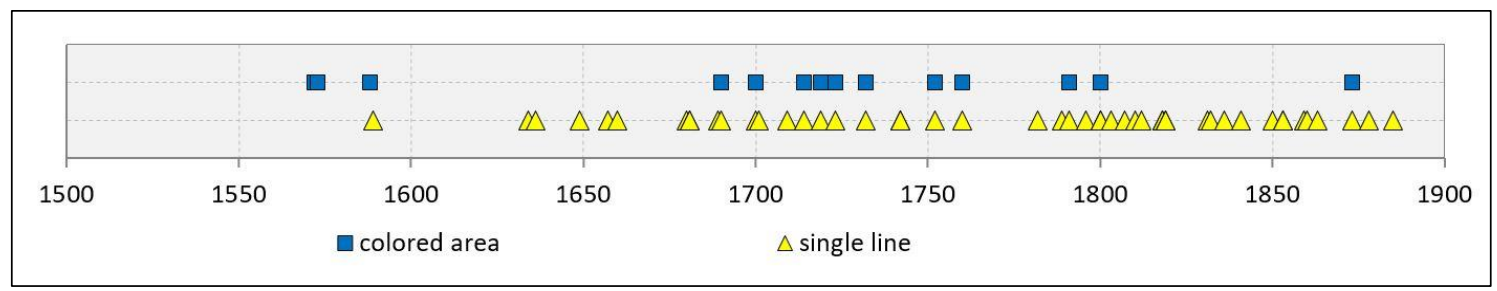

Figure 8. Frequency of showing borders with lines and areas during the period studied.

\section{CONCLUSION AND DISCUSSION}

The main finding of this study is that maps showing the territory of today's Slovenia did not mark borders until the sixteenth century

(Figure 1), and from the seventeenth century onward they almost always marked them. This was most often done using lines, which appear on maps during the entire period studied, followed by colored areas, which was most common on eighteenth-century maps (Figure 8).

Studying old maps is important not only for cartography or historical geography because 
the findings of such research can also influence the everyday lives of people today. Such is also the character of this research, parts of which were included in material for the arbitration procedure to define the border between Slovenia and Croatia.

After the independence of Slovenia and Croatia in 1991, the former internal Yugoslav border became an international border (today a Schengen border), which was never precisely mapped and marked with border stones during Yugoslav times. Following a series of unsuccessful bilateral attempts to resolve the dispute over their land and maritime boundary, Slovenia and Croatia, with the facilitation of the European Commission, agreed on an arbitration process by the Permanent Court of Arbitration in The Hague (in the Netherlands). An arbitration agreement was signed on November 4th, 2009 [19].

In 2012, the Slovenian Ministry of Foreign Affairs ordered preparation of geographical material for the arbitration procedure to determine the Slovenian-Croatian border. In 2013, extensive material was prepared entitled "Geography of the Slovenian-Croatian Border." The old maps and other cartographic sources played an important role in the preparation of this material.
In total, almost exactly four-fifths of the boundary passes along rivers and streams (a hydrographic border) and follows hill ridges (an orographic border). Therefore in examining old maps and borders, special focus was placed on the changing courses of rivers through history.

The most important among the historical maps were three Habsburg military land surveys. The first survey was carried out between 1784 and $1787[20 ; 21]$, the second one between 1806 and 1869 [22], and the third one between 1869 and 1887 [23]. Due to their scale (1:28,880 for the first two and 1:25,000 for the third), the military surveys are suitable for studying changes in the courses of larger rivers.

In addition to military purposes, cartographic data in the Habsburg Monarchy were also gathered for the land cadaster to catalogue properties for tax purposes $[24 ; 25]$. The Franciscan cadaster was used for all of Slovenian territory between 1818 and 1828 $[25 ; 26]$, and its updated (revised) version between 1869 and 1887 [27], both at a scale of $1: 2,880$.

Figure 9 shows an example of the changing course of the Mura River from the mideighteenth century onward.

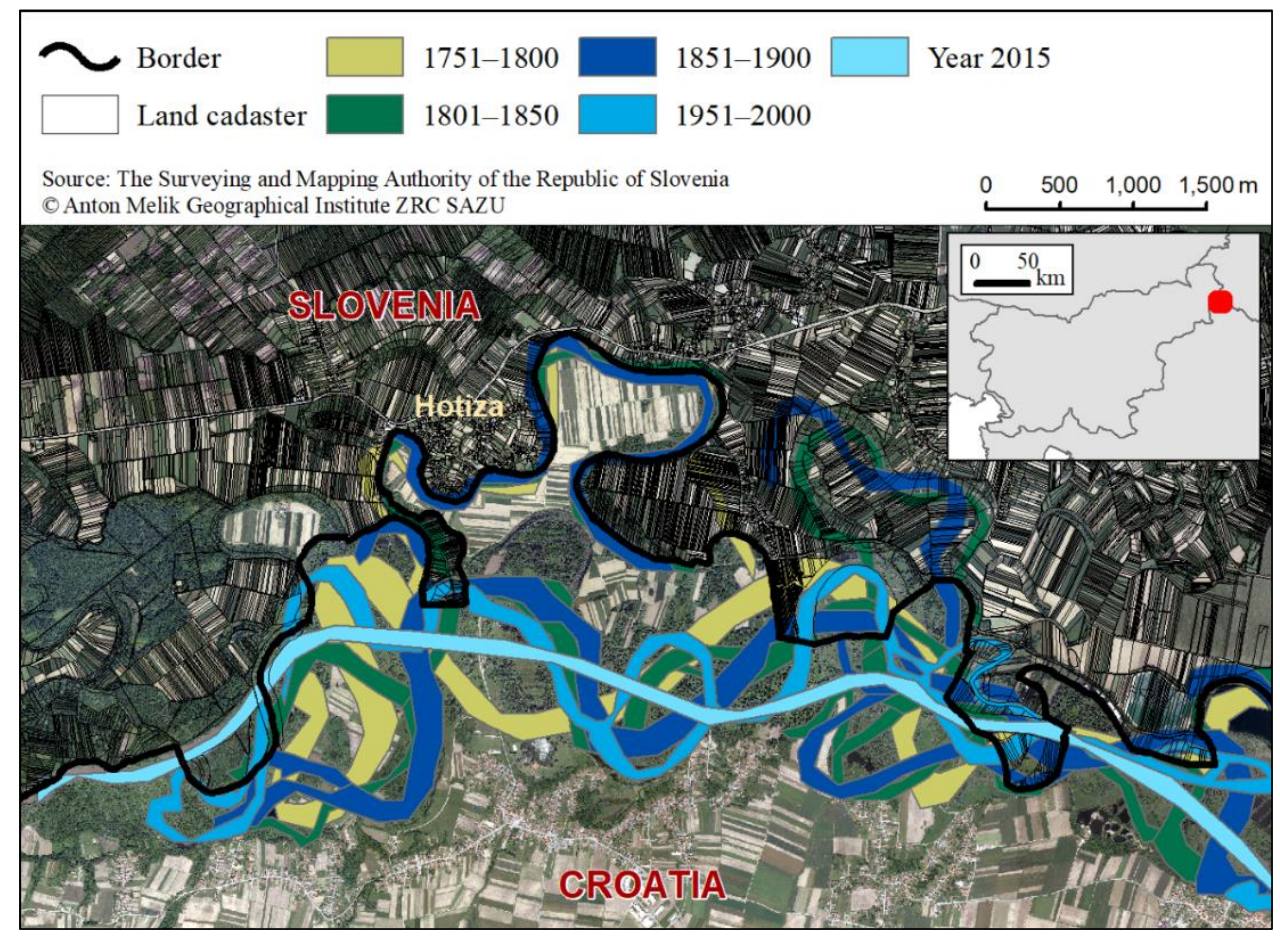

Figure 9. The changing course of the Mura River at Hotiza in the last two hundred years based on cartographic sources. 
Of course, modern geospatial technologies, especially geographic information systems, with data from various digital cartographic sources (historical and recent aerial images, precise digital elevation models (LiDAR), and satellite images) also played an important role in the preparation of geographical bases for the arbitration procedure.

This confirms the applied value of modern geography, as well as historical geography and cartography.

ACKNOWLEDGEMENT: The authors acknowledge financial support from the Slovenian Research Agency (program no. P6-0101: Geography of Slovenia, and project no. J6-6830: Phenomenon of Border Rivers).

\section{REFERENCES}

[1] Brunet-Jailly E. The state of borders and borderlands studies 2009: A historical view and a view from the Journal of Borderlands Studies, Eurasia Border Review, Hokkaido, vol. 1(1), pp 1-15, 2010.

[2] Boundary Classification Systems. Accessible at: http://eurekaencyclopedia.com/index.php/Category:Boundary_Classification_Systems. Accessed 20 Fen 2018

[3] Bognar A. Utjecaj prirodno-geografske osnove na razvoj hrvatsko-slovenske granice, Dela, Slovenia, vol. 16, pp 61-72, 2001.

[4] Lazius W. Ducatus Carniolae et His triae una cum Marcha Windorum, Cartographic material, Scale proximately 1:500.000, 1561 .

[5] Delano-Smith C. Signs on Printed Topographical Maps, ca. 1470-ca. 1640, The history of cartography, Cartography in the European Renaissance, United States of America, United Kingdom, vol. 3, pp 528590, 2007.

[6] de Witt Ducatus Carintiae et Carniolae Cilleiae Comitatus, Cartographic material, Scale proximately 1:500.000, c1680.

[7] Delisle G. Kaartje van t Hertogdom Crain, Cartographic material, Scale proximately 1:320.000, 1791.

[8] Slukan Altić M. Povijesna kartografija - kartografski izvori u povijesnim znanostima, Yugoslavia, 2003.

[9] Gašperič P. Razvoj metod prikaza kartografskih elementov na starih zemljevidih ozemlja Slovenije, Unpublished PhD Thesis Department of Geography, Faculty of Humanities, University of Primorska, Slovenia, 2016.

[10] Peterca M. \& Radošević N. \& Milisavljević S. \& Racetin F. Kartografija, Yugoslavia, 1974.

[11] Lovrić, P. Opća kartografija, Croatia, 1988.

[12] Petrovič D. Topografija in kartografija, Inženirska zbornica Slovenije, Examination program, Slovenia, 2010. Accessible at: http://www.izs.si/fileadmin/dokumenti/strokovni_izpiti/msgeo/2010_topografija_in_kartografija.pdf.

[13] Vrišer I. Uvod v geografijo, Yugoslavia, 1992.

[14] Robinson A. H. \& Morrison J. L. \& Muehrcke P. C. \& Kimerling A. J. \& Guptill S. C. Elements of Cartography, United States of America, 1995.

[15] Maps and Cartography. GIS Research \& Map Collection. Maps Tuturial: The Elements of a Map. United States of America, 2015. Accessible at: https://www.bsu.edu/libraries/collections/gcmc/tutorials/pdfs/mapscartographymapelements.pdf

[16] Fridl J. Metodologija tematske kartografije nacionalnega atlas Slovenije, Geografija Slovenije, Slovenia, vol. 2, 1999.

[17] Bertin J. Graphics and Graphic Information-Processing, Germany, United States of America, 1981.

[18] Rojc B. Barve v tematski kartografiji, Yugoslavia, 1979.

[19] Arbitration Agreement between Government the Republic of Croatia and the Government Republic of Slovenia. The Permanent Court of Arbitration, The Hague, 4 November 2009. Accessible at: https://pcacases.com/web/sendAttach/2165. Accessed 20 Fen 2018

[20] Rajšp V. Slovenija na vojaškem zemljevidu 1763-1787 (Josephinische Landesaufnahme), Geodetski vestnik, Slovenia, vol. 40, pp 68-71, 1996.

[21] Zorn M. Jožefinski vojaški zemljevid kot geografski vir. Geografski vestnik, Slovenia, vol. 79(2), pp 129-140, 2007. 
[22] Timár G. System of the 1:28,800 scale sheets of the Second military survey in Tyrol and Salzburg, Acta geodaetica et geophysica Hungarica, Hungary, vol. 44(1), pp 95-104, 2009. DOI:10.1556/AGeod.44.2009.1.9

[23] Molnár G. \& Podobnikar T. \& Timár G. Mozaičenje listov kart merila 1 : 75.000 tretje vojaške izmere Avstro-Ogrske, Geodetski vestnik, Slovenia, vol. 53(3), pp 459-468, 2009.

[24] Ribnikar P. Zemljiški kataster kot vir za zgodovino, Zgodovinski časopis, Yugoslavia, vol. 36(4), pp 321-337, 1982.

[25] Golec B. Zemljiški katastri 18. in 19. stoletja kot vir za stavbno, gradbeno in urbanistično zgodovino slovenskega ozemlja, 2. del, Arhivi, Slovenia, vol. 33(2), pp 339-396, 2010.

[26] Drobnik M. Reproduciranje franciscejskega katastra, Arhivi, Slovenia, vol. 25(2), pp 65-76, 2001.

[27] Seručnik M. Reambulančni kataster za Kranjsko, Kronika, Slovenia, vol. 57(3), pp 491-504, 2009. 